\title{
Pedestrian Perceptions and the New-Normal
}

\author{
A Case Study on Jalan Khatib Sulaiman, Padang \\ Angelalia Roza ${ }^{1 *}$, Silvia Mulyani ${ }^{1}$, Andi Mulya Rusli², Muchlisin ${ }^{3}$ \\ ${ }^{1}$ Institut Teknologi Padang, Indonesia \\ ${ }^{2}$ Ministry of Public Works and Public Housing, Director General of Highways, Indonesia \\ ${ }^{3}$ Universitas Muhammadiyah Yogyakarta \\ *Corresponding author. angelaliaroza@gmail.com
}

\begin{abstract}
The Public Works and Spatial Planning (PUPR) Office of Padang, Indonesia has currently focused on the agenda of improving pedestrian paths in several areas, including Jalan Khatib Sulaiman. This study aims to evaluate the pedestrian way on Jalan Khatib Sulaiman by examining physical and non-physical aspects. Descriptive qualitative analysis methods were examined and combined by exploring inferential statistical analysis techniques with variables such as the cleanliness, completeness of facilities, etc. A perception analysis approach was carried out to evaluate the comfortability of the pedestrian path. The pedestrian corridor of Jalan Khatib Sulaiman has fulfilled the physical standard of the pedestrian space according to the Guidelines for the National Standardization Agency for Indonesia (BSN) No. 8 of 2000. As a result of this study by examined 12 variables, it showed that the pedestrian way on Jalan Khatib Sulaiman can be categorized as 'comfort'. In terms of pedestrian way optimization, a regulatory approach is needed, such as (1) Using masks on the pedestrian way as a mandatory (2) promoting cleanliness through billboards. Improving facilities on the pedestrian path such as (3) providing a sink/hand washing area or (4) providing hand sanitizer at some points, (5) providing a canopy/protective roof on the pedestrian path, and (6) providing bus stops on the route pedestrian also expected. (7) Enhancing the Cross slope and sidewalk grades was also expected. In the new normal era, the completeness of the facility on pedestrian paths is considered "important" to do (scale 66.64\%).
\end{abstract}

Keywords-pedestrian way, analysis of perceptions, and comfortability

\section{INTRODUCTION}

The city of Padang is the capital of West Sumatra Province, Indonesia. The total population of Padang City in 2019 reached 939,112 people with an area of $694.96 \mathrm{Km}^{2}$. The need for physical infrastructure such as pedestrian paths is essential to support the easiness of accessibility for daily mobility in that city. Therefore, the city of Padang through the Public Works and Spatial Planning (PUPR) Office has attempted to focus on the agenda of constructing the pedestrian path along the $4.1 \mathrm{~km}$ with a total budget of 17.8 billion. One of the pedestrian paths that has been constructed is Jalan Khatib Sulaiman where it has been developed to become a commercial area. Land use is dominated by public service buildings, shopping centers, offices, government buildings, school/campus buildings, hospitals, hotels, and mosques.

At the beginning of 2020, the world was excited by the major disaster of Covid-19. This pandemic has suffered almost all sectors particularly in economy and social interaction worldwide. The real impact that many companies go bankrupt, many layoffs, and groceries are difficult to find $[1,2]$. In this regard, this condition also has a potential effect on the pedestrian path's users, especially when interacting and utilizing space and facilities on the pedestrian path. Based on that condition, exploring the pedestrian path in the corridor of Khatib Sulaiman during the Covid-19 pandemic would be interesting to study. Besides examining Jalan Khatib Sulaiman as a study location, this study also takes the Transmart area, Padang as a case study in Padang City.

Thus, this research aims to explore 2 purposes which are : (1) Knowing the existing conditions and supporting facilities on the pedestrian route on Jalan Khatib Sulaiman (2) Analyzing the perceptions of pedestrian lane users regarding the comfort aspects of the pedestrian path on Jalan Khatib Sulaiman, and compiling recommendations for the development of pedestrian paths in the study area.

\section{RESEARCH METHOD}

This research uses descriptive qualitative analysis techniques. Primary data collection methods for research using observation and measurement techniques in analyzing land use. Primary data collection is also through documentation techniques and interviews with a questionnaire instrument. Field surveys and interviews for data collection were carried out for 1 month (in June 2020) at the research location in the morning, afternoon, and evening by following 
the Indonesian Covid-19 protocol. Meanwhile, secondary data to support the analysis were collected through literature studies.

The sampling technique in this study used an accidental systematic sampling technique which was reported to be successful in previous research [3]. The sample is pedestrians who happen to be encountered and are considered appropriate to be the sample at the research location. In the case study Jalan Khatib Sulaiman, Padang city, for this case study the Transmart area used 100 samples.

\subsection{Analysis Approaches}

Analysis of the condition of the pedestrian path of Jalan Khatib Sulaiman for the Transmart area case study includes analysis of physical and non-physical aspects. The descriptive qualitative analysis method is used to analyze the physical aspects of the pedestrian space through weighting and tabulation. Inferential statistical analysis techniques are also used for non-physical aspects. The analysis is in the form of an assessment of the level of satisfaction, an assessment of the comfort and discomfort factors on the pedestrian path. Pearson correlation moment and Cronbach Alpha are used as indicators to analyze user perceptions in efforts to develop pedestrian paths.

In-depth analysis related to physical and non-physical aspects is needed to optimize and develop the pedestrian path of Jalan Khatib Sulaiman. In many studies, pedestrian path assessment is usually carried out through physical and nonphysical aspects analysis approaches, assessment of pedestrian path quality, Pedestrian Environmental Quality Index, and High Capacity Manual approach [4-9].

\subsubsection{Analysis of Physical Aspects}

Analysis of the observed physical aspects can be; accessibility, gradients, and dimensions of pedestrian paths paving designs, lane pavement materials, street furniture, vegetation, and other supporting elements/facilities. In Indonesia, the actual conditions evaluated refer to the National Standardization Agency (BSN) Guidelines No. 8 of 2000 [10].

\subsubsection{Analysis of Non-Physical Aspects}

In this study, the non-physical aspects analyzed were focused on user characteristics and pedestrian activities on pedestrian paths. Analysis of non-physical aspects in this study was assessed through an analysis of user perceptions of the comfort of the pedestrian space.

In interpreting the results of the analysis data to provide recommendations for development directions, the following stages of analysis are first carried out [11]:

- Coding and tabulation according to the answers to the questionnaire items to assess the comfort score

- Test the validity of variables using Pearson Product Moment at a significant level $(\alpha=0.05)$

- Checking significance of t-test
- Checking the reliability of the instrument using Cronbach Alpha at a significant level $(\alpha=0.05)$ and $\mathrm{df}$ $=\mathrm{N}-2=98$

\section{RESULT}

\subsection{Physical Aspects Condition}

In this research, the observed pedestrian path of Jalan Khatib Sulaiman is $\pm 4.5 \mathrm{~km}$ long, starting from the Presidential Simpang to the front of the Grand Mosque of West Sumatra. In-depth observations were made around the Transmart area, on the left side $\pm 200 \mathrm{~m}$ on the right, $\pm 200 \mathrm{~m}$ long. The curb width observed was 8.6 meters (Figure 1). The sidewalk on Jalan Khatib Sulaiman has a curb as high as 25 $\mathrm{cm}$ which has met the minimum requirements of the Minister of Public Works Decree No 486 of 1998, $(10 \mathrm{~cm})$. The pavement on the sidewalk uses a type of paving block with dimensions of $30 \mathrm{~cm} \times 30 \mathrm{~cm}$ (Fig. 1).

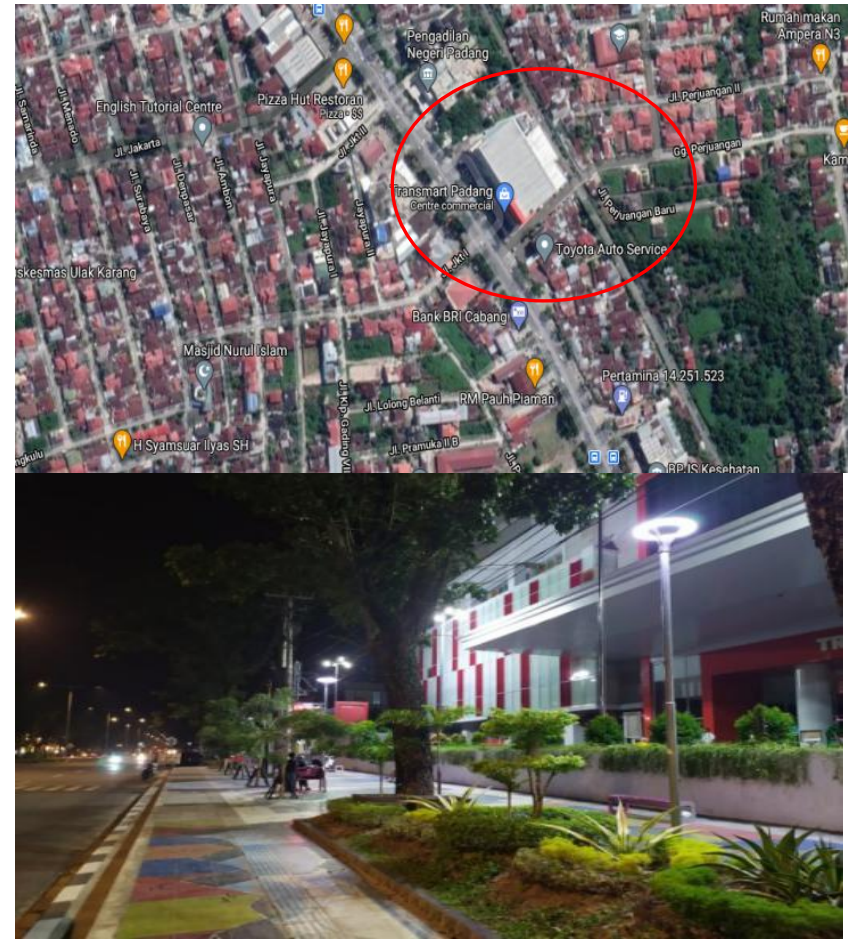

Fig. 1. Condition of the Pedestrian Path of Jalan Khatib Sulaiman.

From a physical perspective, the pedestrian paths on Jalan Khatib Sulaiman, meet the standards for the elements of pedestrian space [10]. The pedestrian way along the Transmart corridor has been equipped with supporting facilities for seating, trash cans, traffic signs, lighting, trees, safety fences, bus stops, and special lanes for disabilities (Fig. 2).

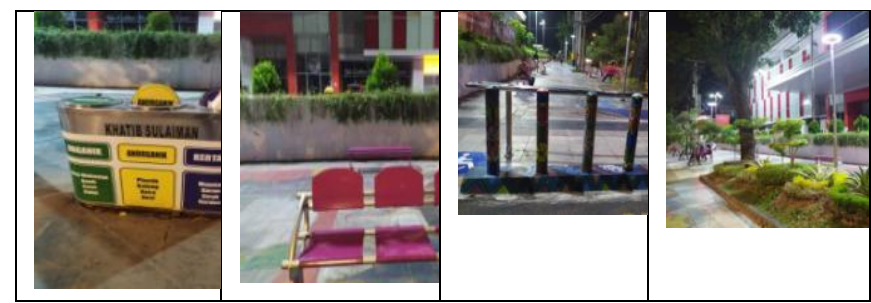




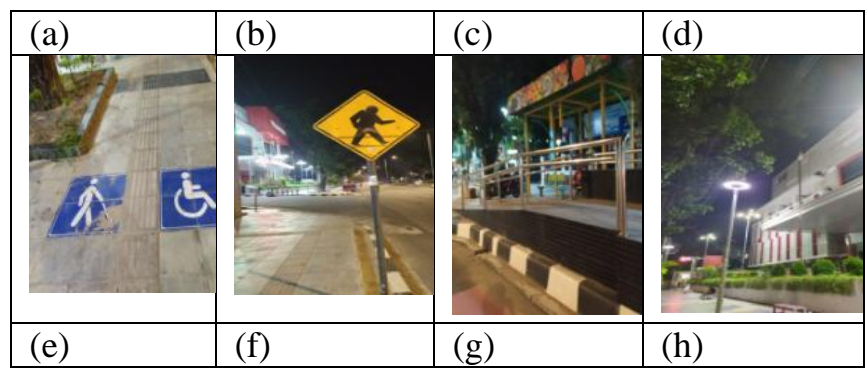

Fig. 2. Supporting Facilities for Pedestrian Lines: (a) Trash cans; (b) Seats; (c) Safety Fence; (d) Trees; (e) Pathways for Disabilities; (f) Traffic signs; (g) Bus Stop; (h) Lighting lamps.

\subsection{Non-Physical Aspects Condition}

Understanding pedestrian behavior in urban areas is beneficial for improving pedestrian comfort and safety, as an effort to improve design and planning of the road and traffic environment [12,13] Pedestrians' perceptions and attitudes often evaluate in some researches to understand how individuals behave on the pedestrian way $[14,15,17,18]$.

In this study, the data analyzed included (1) respondent characteristics, (2) perceptions of pedestrian lane conditions, (3) respondents' comfort and discomfort factors, and (4) Urgency of pedestrian path development.

\subsection{Respondents Characteristics}

Data on the characteristics of respondents who pass the pedestrian path of Jalan Khatib Sulaiman is shown in Table I. The results of the analysis of the characteristics of the respondents (Table I) show that the majority of pedestrian users are women (65\%). Most of the respondents $(56 \%)$ are in the productive age between 20-30 years.

Table I. Respondent's Characteristics

\begin{tabular}{|c|c|c|c|c|c|}
\hline Variable & Data & & Variable & Data & \\
\hline \multirow{2}{*}{ Gender } & Men & $: 35$ & \multirow{6}{*}{ Education } & No School & $: \quad-$ \\
\hline & Women & : 65 & & Elementary School & $: 1$ \\
\hline \multirow{5}{*}{ Age } & $<20$ & $: 31$ & & Junior Shcool & $: 8$ \\
\hline & $20-30$ & $: 56$ & & High School & $: 58$ \\
\hline & $31-40$ & $: 12$ & & University's Degree & $: 33$ \\
\hline & $41-50$ & $: 1$ & & Others & $: 0$ \\
\hline & $>50$ & $: 0$ & \multirow{6}{*}{$\begin{array}{l}\text { Trip } \\
\text { Purposes }\end{array}$} & Shopping & : 38 \\
\hline \multirow{5}{*}{ Occupation } & No Job & $: 18$ & & Working & $: 17$ \\
\hline & Student & $: 52$ & & Sport & $: 5$ \\
\hline & & 12 & & Waiting Transport's & 22 \\
\hline & Employer & & & Mode & \\
\hline & Entrepreneur & : 18 & & Other & : 18 \\
\hline
\end{tabular}

The composition of the respondent's occupations are students (52\%), private employees (12\%), entrepreneurs/traders (18\%). Based on educational characteristics, users of the pedestrian path are high school graduates $(58 \%)$ and diplomas/undergraduate (33\%). Respondents walk on the pedestrian path of Jalan Khatib Sulaiman for shopping activities (38\%), waiting for public transportation (22\%), working activities (17\%), sports activities (5\%); and others (18\%).

\subsection{Perception of Pedestrian Path Conditions}

Conditions for pedestrian paths are evaluated through the question sub item indicator "main function of pedestrian paths". Respondents were given a choice of 8 questions on the main function of the pedestrian path. Respondents can choose more than one option. Through weighting, the main functions of the Pedestrian Path on Jalan Khatib Sulaiman are as follows: (1) a special lane for pedestrians, (2) a space for the beauty of the city and (3) as a waiting room for vehicles, and (4) as a shelter and (5) as a socializing space. However, a small proportion of respondents considered that the pedestrian space also functions as a space for cycling, as an evacuation route.

Respondents' perceptions related to non-physical aspects on the Pedestrian Path of Jalan Khatib Sulaiman were analyzed using inferential analysis techniques. The 12 variables are used to evaluate the comfort of pedestrian path conditions as shown in Table II.

Table II. Pedestrian Path Condition

\begin{tabular}{|c|c|c|c|c|}
\hline $\begin{array}{l}\text { Pedestrian Path } \\
\text { Condition }\end{array}$ & $\begin{array}{l}\text { Correlation } \\
\text { Coeff. ( r) }\end{array}$ & $\begin{array}{l}\text { t- } \\
\text { test }\end{array}$ & $\begin{array}{l}\text { Value } \\
\text { (t) }\end{array}$ & $\begin{array}{l}\text { Validity } \\
\text { (t- test) }\end{array}$ \\
\hline $\begin{array}{l}\text { sun/shade } \\
\text { exposure }\end{array}$ & 0.608 & $\begin{array}{l}7.5 \\
79\end{array}$ & 0.165 & Valid \\
\hline $\begin{array}{l}\text { Scenery Around } \\
\text { the Pedestrian } \\
\text { Path }\end{array}$ & 0.369 & $\begin{array}{l}3.9 \\
29\end{array}$ & 0.165 & Valid \\
\hline $\begin{array}{l}\text { Pedestrian Path } \\
\text { marking }\end{array}$ & 0.467 & $\begin{array}{l}5.2 \\
29\end{array}$ & 0.165 & Valid \\
\hline Vehicle Noise & 0.495 & $\begin{array}{l}5.6 \\
40 \\
\end{array}$ & 0.165 & Valid \\
\hline Bad smell & 0.561 & $\begin{array}{l}6.7 \\
05\end{array}$ & 0.165 & Valid \\
\hline $\begin{array}{l}\text { Shape \& quality } \\
\text { of Pedestrian } \\
\text { pathways }\end{array}$ & 0.427 & $\begin{array}{l}4.6 \\
70\end{array}$ & 0.165 & Valid \\
\hline $\begin{array}{ll}\text { Keamanan Dari } \\
\text { Tindak } \\
\text { Kejahatan }\end{array}$ & 0.511 & $\begin{array}{l}5.8 \\
88\end{array}$ & 0.165 & Valid \\
\hline $\begin{array}{l}\text { Safety On The } \\
\text { Pedestrian Path }\end{array}$ & 0.483 & $\begin{array}{l}5.4 \\
55\end{array}$ & 0.165 & Valid \\
\hline $\begin{array}{l}\text { Pedestrian Path } \\
\text { Cleanliness }\end{array}$ & 0.680 & $\begin{array}{l}9.1 \\
78\end{array}$ & 0.165 & Valid \\
\hline $\begin{array}{l}\text { The materials \& } \\
\text { shape of the } \\
\text { pedestrian path }\end{array}$ & 0.589 & $\begin{array}{l}7.2 \\
11\end{array}$ & 0.165 & Valid \\
\hline $\begin{array}{l}\text { Accessibility } \\
\text { from \& to the } \\
\text { Pedestrian Line }\end{array}$ & 0.553 & $\begin{array}{l}6.5 \\
71\end{array}$ & 0.165 & Valid \\
\hline $\begin{array}{l}\text { Supporting } \\
\text { Facilities }\end{array}$ & 0.578 & $\begin{array}{l}7.0 \\
15\end{array}$ & 0.165 & Valid \\
\hline
\end{tabular}

Respondents' Perceptions about the condition of the pedestrian path can be seen in Table III. The total score is 4380 (Table III) over 6000, thus the comfort percentage value is $73 \%$ (Fig. 3). It can be stated that the pedestrian path on Jalan Khatib Sulaiman is "Comfort" (Interval score of $60<\mathrm{N}<80$ ). 
Table III. Perceptions Score of the Pedestrian Path Condition

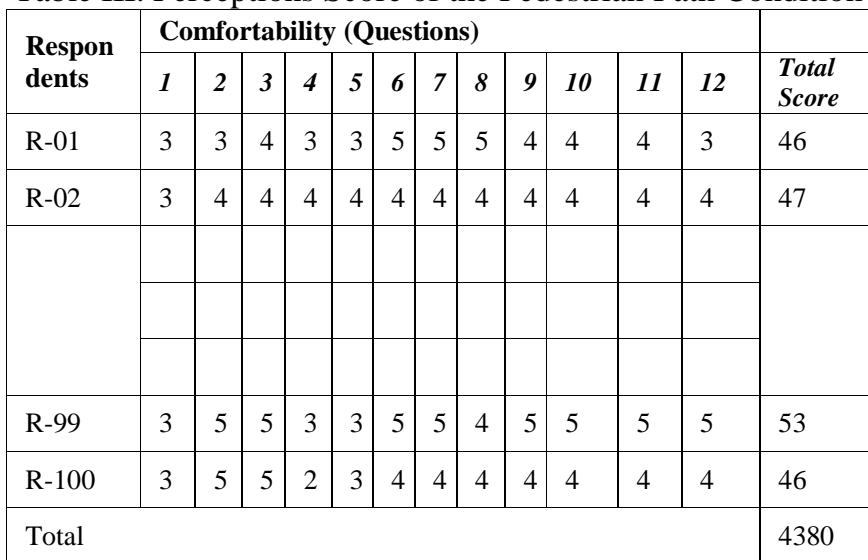

\begin{tabular}{|l|}
\hline Very Comfortable \\
Comfortable \\
Re... \\
Really uncomfortable \\
\hline \multicolumn{2}{|c|}{ Comfort scale $73 \%$} \\
\hline
\end{tabular}

Fig. 3. Interval scale of comfort (Source: Research Result, 2020)

The category of "comfortable" according to the respondent's perception is related to the availability of supporting facilities on the pedestrian way.

\subsection{Perception of Pedestrian Path Conditions}

Respondents were asked to assess the comfort aspects of the pedestrian paths and the inconvenience aspects of the pedestrian paths. It was found that the factors that influenced the respondents' comfort were on the pedestrian route as follows (Fig. 4).

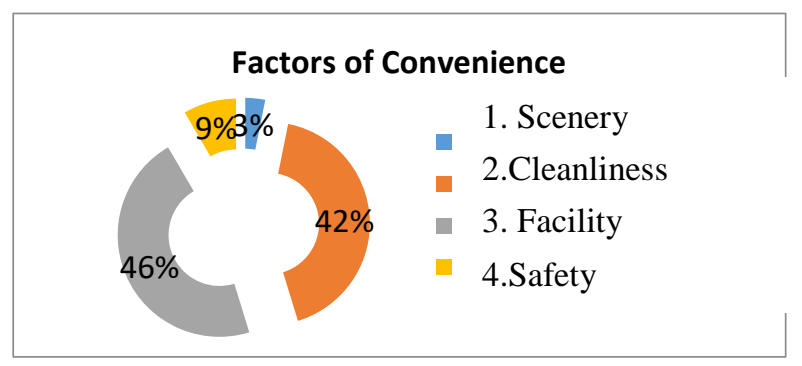

Fig. 4. Convenience Factors on Pedestrian Path

The variables that affect the perceptions of user convenience are (Fig. 4): Pedestrian facilities (46\%), cleanliness of the sidewalks (42\%), safety factor $(9 \%)$, and scenery (3\%). In general, the physical aspect is the convenience key based on pedestrian perception.

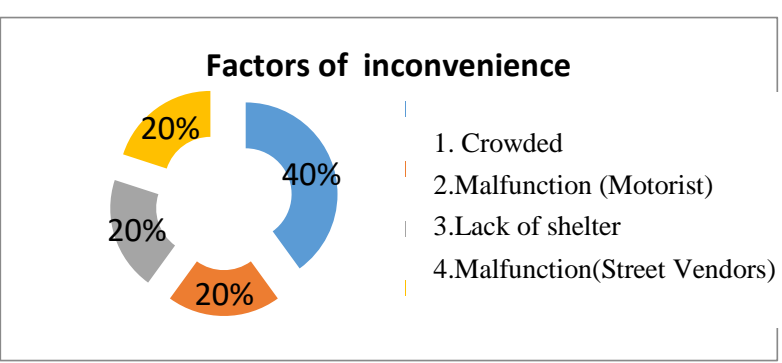

Fig. 5. Inconvenience Factors of Pedestrian Patht

Furthermore, for the analysis of the aspect of discomfort, the following results were obtained (Fig. 5). It can be seen that the variable affecting users' perception of discomfort is crowded $(40 \%)$ so that limited space is created; Sidewalk malfunctions $(40 \%)$ both by motorists and by street vendors. While the rest (20\%) is due to lack of shelter $(20 \%)$.

\subsection{The Urgency of Pedestrian Pedestrian Facilities}

Several questions have been compiled and analyzed to recommend what facilities should be provided on the pedestrian path in the 'new normal'. The urgency of pedestrian supporting facilities was evaluated by using similar steps (Table 3). The score obtained is 1666 out of a total score of 2500 . So referring to the importance scale interval, the score of $66.64 \%$ is in the "important" category.

Pedestrian facilities that need to be served for the 'New Normal' are determined in Table IV. The reliability test using Cronbach Alpha meets the criteria. By using Pearson Product Moment and the t-test criteria all variables consider valid (Table IV). It means that all data considered reliable and valid.

Table IV. Pedestrian Path Condition

\begin{tabular}{|c|c|c|c|c|}
\hline $\begin{array}{l}\text { Pedestrian Path } \\
\text { Condition }\end{array}$ & $\begin{array}{l}\text { Correlation } \\
\text { Coef. ( r ) }\end{array}$ & t-test & $\begin{array}{l}\text { Value } \\
\text { (t ) }\end{array}$ & $\begin{array}{l}\text { Validity } \\
\text { (t- test) }\end{array}$ \\
\hline $\begin{array}{l}\text { hand washing area } \\
\text { ( the sink) on some } \\
\text { points around the } \\
\text { pedestrian } \\
\text { crosswalk }\end{array}$ & 0.654 & 8.549 & 0.165 & Valid \\
\hline $\begin{array}{l}\text { Hand sanitizers } \\
\text { should be served on } \\
\text { some points around } \\
\text { the pedestrian } \\
\text { crosswalk }\end{array}$ & 0.730 & 10.572 & 0.165 & Valid \\
\hline $\begin{array}{l}\text { Obligation to use } \\
\text { masks along the } \\
\text { pedestrian path }\end{array}$ & 0.603 & 7.491 & 0.165 & Valid \\
\hline $\begin{array}{l}\text { Cleanliness } \\
\text { campaign through } \\
\text { Billboards }\end{array}$ & 0.526 & 6.127 & 0.165 & Valid \\
\hline $\begin{array}{l}\text { Marking } \\
\text { Pedestrian } \\
\text { crosswalk } \\
\text { /pathways }\end{array}$ & 0.483 & 5.464 & 0.165 & Valid \\
\hline $\begin{array}{l}\text { Condition of } \\
\text { Pedestrian pathways }\end{array}$ & 0.582 & 7.084 & 0.165 & Valid \\
\hline Bus Stop facilities & 0.483 & 5.464 & 0.165 & Valid \\
\hline
\end{tabular}




\section{DISCUSSION}

Based on the result, we argue that improving services are the key factors to bring comfort to the pedestrian pathway. The development of pedestrian paths in new normal conditions is important to be directed at regulatory approaches such as (1) the mandatory use of masks on pedestrian paths and (2) campaigns to keep cleanliness through billboards. Development needs to be directed at increasing the supporting elements on the pedestrian path, such as (3) providing a sink/hand washing area and (4) hand sanitizer at certain points (5) providing a canopy / protective roof on the pedestrian path, and (6) providing bus stops on the route pedestrian. As well as improvements to cross slope and grade.

The thing that attracts attention is the sidewalk effective width which is closely related to the obstacle on the pedestrian path. Sidewalk malfunction will result in a reduction in the effective width of the sidewalk, a reduction in pedestrian space as well as an increase in interference on the sidewalk. A study reported that the required pedestrian space is about 10 $\mathrm{cm}$ of lateral spacing [19]. However, in Indonesia, further study is needed.

The existence of permanent and temporal obstacles that have been reported as a change in the function of pedestrian paths, such as illegal parking, street vendors [8] is also confirmed through this research.

In terms of pedestrian way optimization of Jalan Khatib Sulaiman, users hope that there will be control of sidewalk malfunctions, for example as a parking lot for motor vehicles and as a space for selling street vendors. The users also really expect the increased shade on the pedestrian path on the Khatib Sulaiman Line. This can be done by installing a canopy along the pedestrian path, or shade trees (vegetation) to protect pedestrians when the weather is hot or rainy. Apart from that, regarding the cleanliness and beauty around the pedestrian paths, respondents expect an increase in the number of lights, park benches, and trash cans.

The good pedestrian route would support the government's Transit-Oriented Development plan. Improvement of pedestrians affects the intention to walk for short (less than $100 \mathrm{~m}$ ) and medium (100-500 m) distance rather than using a bus [19].

In addition to the user perception approach that has been discussed in the study, further research is also recommended to assess the quality of pedestrian paths in the New Normal Era with the PEQI (Pedestrian Environmental Quality Index) approach and to assess the service level of pedestrian paths using HCM and regulations. Minister of Public Works No: 03 / PRT / M / 2014 concerning Guidelines for Planning, Provision, and Utilization of Pedestrian Network Infrastructure and Facilities in Urban Areas.

\section{CONCLUSION}

Based on the data and analysis that has been presented, the following conclusions can be drawn:
- According to the minimum standards for pedestrian paths in shops/shopping areas, pedestrian pathways Jl. Khatib Sulaiman has fulfilled the physical aspects and is equipped with facilities such as trash cans; seat; safety fence; Tree; Pathways for Disabilities; Traffic signs; Bus Stop; and Lighting. The sidewalk on Jalan Khatib Sulaiman has a curb height of $25 \mathrm{~cm}$ which meets the minimum requirements of the Minister of Public Works Decree No 486 of 1998, $(10 \mathrm{~cm})$.

- The results of the analysis of the perception of the conditions of the pedestrian paths on Jalan Khatib Sulaiman prove that the pedestrian path is on a comfortable, comfortable (Scale 73\%).

- The pedestrian lane on Jalan Khatib Sulaiman has now fulfilled its main function in addition to its main function apart from being (1) a special lane for pedestrians, it also functions as (2) a space for the beauty of the city and (3) as a waiting room for vehicles and (4) as a space shelter and (5) as a socializing space. However, a small proportion of respondents considered the pedestrian space as a space for cycling and as an evacuation route.

- As an effort to increase the perception of pedestrian comfort in the new normal era, the development of facilities on the pedestrian path is considered "important" to do (on a scale of $66.64 \%$ ). To optimize, a regulatory approach is needed, such as (1) mandatory use of masks on pedestrians and (2) campaigns for cleanliness through billboards. Development also needs to be directed at increasing the supporting elements on the pedestrian path, such as (3) providing a sink/hand washing area and (4) hand sanitizers at certain points (5) providing a canopy / protective roof on the pedestrian route and (6) providing bus stops at certain points. pedestrian path. As well as repair of Cross slope and sidewalk grades.

\section{ACKNOWLEDGMENT}

The author would like to express the deepest gratitude to Institut Teknologi Padang,cUniversitas Muhammadiyah Yogyakarta, Kementrian PUPR and all parties involved in conducting this study.

\section{REFERENCES}

[1] S. Katta, A. Badger, M. Graham, K. Howson, F. UstekSpilda, and A. Bertolini, "(Dis) embeddedness and (de) commodification: COVID-19, Uber, and the unravelling logics of the gig economy," Dialogues in Human Geography, vol. 10, no. 2, pp. 203-207, 2020.

[2] P. Seetharaman, "Business models shifts: Impact of Covid-19," International Journal of Information Management, vol. 54, p. 102173, 2020.

[3] L. N. Ikhsani, and P. Khadiyanta, F. "User's Perception Towards Pedestrian Facility at Pemuda Street Magelang City", RUANG, Vol. 1 No. 3, 2015, 111-120, 2015.

[4] E., D. Septika. "Tingkat Kenyamanan Jalur Pejalan Kaki Jalan Asia Afrika, Bandung,"Prosiding Temu Ilmiah IPLBI. A111-A116, 2016.

[5] Y. Desi. "Analysis of Pedestrian Walk Area based on Law in Hr Soebrantas Street" [Analisa Ruang Pejalan 
Kaki Preferensi Peraturan Perundangan Pada Ruas Jalan Hr Soebrantas], Jurnal Sainstek STT Pekanbaru, Volume 4 No 2, 2016.

[6] M. S. Dwi. " The Utilization of Pedestrian Walk in Commercial Corridor in Pemuda Street, MAgelang City" [Pemanfaatan Pedestrian Ways di Koridor Komersial di Koridor Jalan Pemuda Kota Magelang], Jurnal RUAS, Volume 15 No 1, Juni 2017, ISSN 1693-3702.

[7] R. Sanjaya, Soedarsono, R. Mudiyono. "Analysis of Function and Comfortability of Pedestrian Walk in Pangkalan Bun City" [Analisis Fungsi Dan Kenyamanan Jalur Pedestrian Kawasan Di Kota Pangkalan Bun (Studi Kasus : Bundaran Pancasila)], 2017.

[8] H.M. Rahmi \& P. Khadiyanta. "Study on the Quality and Level of Service in Pedestrian Walk in Khatib Sulaiman Street, Padang City" [Kajian Kualitas dan Tingkat Pelayanan Jalur Pedestrian di Koridor Jalan Khatib Sulaiman Kota Padang], Teknik PWK (Perencanaan Wilayah Kota), Vol 7(4), 2018, 223-232, http://ejournal3.undip.ac.id/index.php/pwk

[9] S. Marisamynathan \& P. Vedagiri. "Pedestrian perception-based level-of-service model at signalized intersection crosswalks," J. Mod. Transport. (2019) 27(4):266-281 https://doi.org/10.1007/s40534-01900196-5, 2019.

[10] Pedoman Badan Standardisasi Nasional (BSN) No. 8 Tahun 2000, Pedoman Penyediaan dan Pemanfaatan Prasarana dan Sarana Ruang Pejalan Kaki di Perkotaan,Gugus Kerja Bidang Penataan Ruang Permukiman, Indonesia.

[11] P.A.S.F.D. Silva, "The Importance of Pedestrian Spaces", Master in Civil Engineering - 2007/2008 - Department of Civil Engineering, Faculty of Engineering, Faculdade de Engenharia da Universidade do Porto, Porto, Portugal, 2008

[12] E. Papadimitrioua, S. Lassarreb, \& G. Yannisa, "Human factors of pedestrian walking and crossing behavior,"
Transportation Research Procedia , 25 (2017) 20022015, 2017.

[13] Y. Ni, Y. Cao, K. Li. "Pedestrians' Safety Perception at Signalized Intersections in Shanghai," Transportation Research Procedia, 25 (2017) 1955-1963, 2017.

[14] C. Torres, L. Sobreira, M. Castro-Neto, F. Cunto, A. Vecino-Ortiz, K. Allen, A. Hyder, \& A. Bachani. "Evaluation of Pedestrian Behavior on Mid-block Crosswalks: A Case Study in Fortaleza-Brazil", https://www.frontiersin.org/researchtopics/11429/advances-in-road-safety-planning), 2020.

[15] R. Zhou, \& W. J. Horrey. "Predicting adolescent pedestrians' behavioral intentions to follow the masses in risky crossing situations," Transportation Research Part F: Traffic Psychology and Behaviour, Volume 13, Issue 3, 2010, Pages 153-163, ISSN 1369-8478,.

[16] H. Sukhadia, S.M. Dave, J. Shahc, D. Rathvad "The Effect of Events on Pedestrian Behavior and its Comparison with Normal Walking Behavior in CBD Area in Indian Context, Transportation Research Procedia, 17 ( 2016 ) 653-663, 2016.

[17] Y. Xu, Y. Li, F. Zhang "Pedestrians' intention to jaywalk: Automatic or planned? A study based on a dual-process model in China,"Accident Analysis \& Prevention, Volume 50, 2013, Pages 811-819, https://doi.org/10.1016/j.aap.2012.07.007.,2013.

[18] M. R. Bloomberg \& A. M. Burden, "New York City Pedestrian Level of Service Study, Phase I," (2006).

[19] A. Kusuma, T. Tjahjono, \& D. G. Arisyi. "Pedestrian Perception in Pathway Facilities Improvement," International Conference on Transportation and Development, 2018. 